\title{
Collaboration Amid Crisis
}

\author{
Elizabeth C. Lamoste, J.D.* and Peter D. Jacobson, J.D., MPH**
}

TABLE OF CONTENTS

I. INTRODUCTION

II. CONTEXT ON THE FLint WATER CRisis

III. THE POTENTIAL OF INTERPROFESSIONAL COLLABORATION IN THE Flint WATER CRISIS 46

A. How Can Interprofessional Collaboration Help Alleviate Harm in the Flint Water Crisis?

B. Could Interprofessional Collaboration Have Prevented the Flint Water Crisis

IV. StRENGTHENING INTERPROFESSIONAL COLlaboration BEYONG THE FLINT WATER CRISIS . 50

V. CONCLUSION. 52

\section{INTRODUCTION}

The 2015 "Interprofessional Collaboration in Public Health Law and Policy: Moving the Needle on Social Determinants of Health" Symposium provided participants with an invaluable opportunity to discuss how interprofessional collaboration can help focus attention on the social determinants of health and potentially improve public health outcomes as a consequence. In the journey to improve social determinants of health, the public health community must examine the role of interprofessional collaboration from another dimension. In addition to identifying opportunities to address the social determinants of health to improve public health outcomes, the public health community also needs to identify events and issues that stand to threaten public health outcomes by worsening certain social determinants of health. Then, the public health community needs to encourage the development and implementation of interprofessional collaboration to help prevent or mitigate such events and issues.

While some of these events can be natural disasters, which are often nearly impossible to prevent-but possible to mitigate-other events can be preventable man-made public health crises. Specifically, this essay offers a high-level reflection upon one particular preventable public health crisis-the ongoing lead exposure and contamination problems in Flint, Michigan, now commonly referred to as the Flint Water Crisis. ${ }^{1}$ The authors acknowledge that this situation is complicated and requires more research and analysis than this essay can provide, especially since the Flint

* Elizabeth C. Lamoste, J.D., is a graduate of the University of Michigan Law School.

** Peter D. Jacobson, JD, MPH, is Professor of Health Law and Policy at the University of Michigan School of Public Health. He received his JD from the University of Pittsburgh School of Law, and MPH from the UCLA School of Public Health.

${ }^{1}$ This article focuses on events in and related to the Flint Water Crisis as of summer 2016, and recognizes that there may be updates between summer 2016 and the publication date of this essay. 
Water Crisis is still ongoing. Even so, the authors argue that the public health community can start to learn from what is currently known. Here, the authors argue that interprofessional collaboration could have helped to prevent, or more effectively mitigate the Flint Water Crisis. ${ }^{2}$ The authors also assert that the Flint Water Crisis should serve as a warning and inspiration to create a stronger infrastructure to promote interprofessional collaboration and to avoid and mitigate other preventable man-made public health crises in the future.

\section{CONTEXT ON THE FLINT WATER CRISIS}

The authors acknowledge that the Flint Water Crisis is factually complicated and requires significantly more research and analysis that this essay can provide individually. The purpose of this section intended to provide an overview of information relevant to understanding aspects of the Flint Water Crisis.

Flint, Michigan is a city that has been deeply connected to the auto industry since the 1900s. For example, General Motors was founded in Flint in $1908 .^{3}$ During the 1950s, General Motors' largest manufacturing complex was located in Flint, and for a time Flint was second only to Detroit nationwide in automobile manufacturing. ${ }^{4}$ Flint was, and is still, nicknamed Vehicle City. ${ }^{5}$ In large part because of the automobile industry, Flint was a prosperous city. After the 1960s, as the automobile industry's presence in Flint declined, Flint also became less prosperous by several measures. ${ }^{6}$ Unemployment rose, and the city's population declined.

Flint is a city that has struggled with poverty and economic decline in recent decades, especially since the $1980 \mathrm{ss}^{7}$ More recently, Flint has experienced a population decline of $18 \%$ from $2000-2010^{8}$. In 2014 the population fell below 100,000 for the first time since the 1920 s. $^{9}$ In 2010 , Flint's unemployment rate was $23.2 \%$, and its median income was $\$ 28,535 .{ }^{10}$ In 1990 , Flint's

2 See, e.g., Jake May, 100 Faces of Flint Residents Bring Water Crisis to Life, THE FuINT J., http://www.mlive.com/flintwater/ [https://perma.cc/559M-JFRW] (last visited Oct. 16, 2016); see also Flint Water Crisis, NBC NEws http://www.nbcnews.com/storyline/flint-water-crisis [https://perma.cc/YW9Y-LZS6] (last visited Oct. 16, 2016).

${ }^{3}$ Ron Fonger, 104 Years Ago Today: General Motors was Born in Flint, MLIVE (Sept. 16, 2012, 8:00 AM), http://www.mlive.com/ [https://perma.cc/TV63-VXQE].

4 Flint, ENCYCLOPEDIA BRITANNICA (Sept. 1, 2016), https://www.britannica.com [https://perma.cc/88KU-NEAL].

${ }^{5} \mathrm{Id}$.

${ }^{6}$ For a more detailed discussion of the history of Flint, Michigan, See, e.g., JOHN W. DAY \& Charles Hall, America's Most Sustainable Cities and Regions: Surviving the 21st Century Megatrends 47-52 (2016).

7 Eric Scorsone \& Nicolette Bateson, Long-Term Crisis and Systemic Failure: TAKing the Fiscal Stress of AmericA’s Older Cities Seriously, Case Study: City of Flint, Michigan 6, 7 (Michigan State University Extension, Sept. 2011), https://www.cityofflint.com [https://perma.cc/ZUG4-VJN2].

${ }^{8} \mathrm{Id}$. at 2.

${ }^{9}$ Ron Fonger, Flint's Population Falls below 100,000 for First Time since the 1920s, Mlive (May 22, 2014, 11:50 AM) http://www.mlive.com/ [https://perma.cc/PD2U-YQGS].

${ }^{10}$ SCORSONE \& BATESON, supra note 7 , at 6. 
poverty level was $30.6 \%$, and it increased to $34.9 \%$ in $2009 .{ }^{11}$ In 2015 , Flint's poverty level was $41.2 \%$, and median household income was $\$ 24,862 .^{12}$

The City of Flint has also faced fiscal difficulties since the early 2000s. ${ }^{13}$ In June 2010, Flint's General Fund ended with an accumulated deficit of \$14.6 million, the third consecutive year of ending in a deficit position. ${ }^{14}$ Flint had been facing the simultaneous challenges of maintaining solvency amidst deficits and limitations in cash flow for several years. ${ }^{15}$

Michigan state law has allowed the state to put a local government in a state of receivership. ${ }^{16}$ In 1990, the Local Government Fiscal Responsibility Act, also known as Public Act 72, was passed, which allowed State officials to intervene in local governments that experience serious financial emergencies by appointing emergency financial managers. ${ }^{17}$ Under Public Act 72 , a financial review of a local government could be requested in certain circumstances. ${ }^{18}$ The review would determine that there was one of the following: no serious financial problem; a serious financial problem but an adopted consent decree; or a local government financial emergency exists because a problem exists but there is no consent decree in place. ${ }^{19}$ In such circumstances, the governor was to assign responsibility for managing the emergency to a local emergency financial assistance loan board, which would appoint an emergency financial manager ("EFM"). ${ }^{20}$ The EFM would be responsible for writing and implementing a financial plan to resolve the emergency, and the governor would have the ability to revoke the declaration of financial emergency after receiving a recommendation from the local emergency financial assistance loan board. ${ }^{21}$

Public Act 4, passed in 2011, repealed Public Act 72 and created the position of emergency manager ("EM") to replace the EFM. ${ }^{22}$ Public Act 4 gave the EM some additional powers that EFMs were not granted previously. ${ }^{23}$ Public Act 4 was rejected by a voter referendum in November

${ }^{11} \mathrm{Id}$.

${ }^{12}$ United States Census Bureau, Quick Facts, Flint City, Michigan, http://www.census.gov/ [https://perma.cc/CGK3-77V9].

${ }^{13}$ Mary Doidge et al. The Flint Fiscal PlaybooK: An Assessment of the Emergency MANAGER YEARS (2011-2015) 3 (2015).

${ }^{14}$ SCORSONE \& BATESON, supra note 7, at 11.

15 SCORSONE \& BATESON, supra note 7, at 48.

16 Mich. COMP. LAWs ANN. § 141.1201 et seq. 1990 (West 2013), repealed by 2012 Mich. Pub. Acts $436 \S 1$.

${ }^{17} \mathrm{Id}$.

${ }^{18}$ Mich. Comp. LAws ANN. $\S \S 141.1212-1213$ (West 2013), repealed by 2012 Mich. Pub. Acts $436 \S 1$.

${ }^{19}$ Mich. Comp. LAws ANN. § 141.1215(1)(a)-(c) (West 2013), repealed by 2012 Mich. Pub. Acts $436 \S 1$.

${ }^{20}$ Mich. COMP. Laws AnN. § 141.1218 (West 2013), repealed by 2012 Mich. Pub. Acts 436 $\S 1$.

${ }^{21}$ Mich. Comp. LAwS ANN. $\S \S 141.1220-141.1225$ (West 2013), repealed by 2012 Mich. Pub. Acts $436 \S 1$.

${ }^{22}$ Mich. ComP. LAws ANN. $\S \S 141.1501-141.1531$ (West 2013), repealed by 2012 Mich. Pub. Acts $436 \S 1$.

${ }^{23}$ See Josh Hakala, How did we get here? A look back at Michigan's Emergency Manager Law, MichigAN RADIO (Feb. 3, 2016), http://michiganradio.org [https://perma.cc/898W-NK6B]. 
2012. ${ }^{24}$ A month later, Public Act 436 was passed, which is largely the same as Public Act 4 but immune from referendum because an appropriation from the general fund was added. ${ }^{25}$ Public Act 436 is currently law in Michigan.

Governor Rick Snyder appointed an EM for Flint on November 29, $2011 .{ }^{26}$ Flint also had an EFM appointed from 2002-2004. ${ }^{27}$

One of the financial problems facing Flint was the cost of its water supply, which it had been sourcing from the Detroit River for many years. ${ }^{28}$ In October 2010, the Karengnondi Water Authority ("KWA") was incorporated to provide and distribute water from Lake Huron"2, a closer and potentially cheaper water source, to Flint and other nearby areas-and the project was scheduled to be completed in spring $2017 .^{30}$

In June 2013, Flint's then EM, Ed Kurtz, approved a contract to explore switching from the Detroit River to the Flint River. ${ }^{31}$ On April 25, 2014, Flint switched its water supply to the Flint River from the Detroit River. ${ }^{32}$ Some, such as former Flint Mayor Dayne Walling, were excited and optimistic about the switch in part because of the potential economic opportunity in terms of both reducing Flint's water expenses and creating jobs for Flint residents. ${ }^{33}$

24 Jonathan Oosting, Michigan Proposal 1: Voters Reject Measure, Repeal Controversial Emergency Manager Law, MLIVE (Nov. 7, 2012, 12:08 PM), http:/www.mlive.com/ [https://perma.cc/36SP-QEPF].

${ }^{25}$ While Michigan voters can generally repeal laws by referendum, the Michigan Constitution provides an exception for bills that appropriate money. See MICH. CONST. art. IV. § 34 ("Any bill passed by the legislature and approved by the governor, except a bill appropriating money, may provide that it will not become law unless approved by a majority of the electors voting thereon"); see also Rick Pluta, Some Laws Shielded from Voter Referendum, MicH. RADIO (Jun. 27, 2011), http://michiganradio.org [https://perma.cc/W6Y3-CG4R].

${ }^{26}$ Kristin Longley, Flint Emergency: Timeline of State Takeover, MLIVE (Dec. 1, 2012, 7:01 AM), http://www.mlive.com/ [https://perma.cc/9VYL-3BQU].

${ }^{27}$ Mary Doidge et al. The Flint Fiscal Playbook: An Assessment of the EMERgency MANAGER YEARS (2011-2015) 3 (2015).

${ }^{28}$ Dominic Adams, Closing the Valve on History: Flint Cuts Water Flow from Detroit After Nearly 50 Years, MLIVE (Apr. 25, 2014, 4:52 PM), http://www.mlive.com/ [https://perma.cc/2J9F-TF9F] (last updated Jan. 17, 2015).

29 Jacob Carah, Last Portion of KWA Pipeline Installed, The Detroit News (July, 11, 2016, 3:07 PM), http://www.detroitnews.com/ [https://perma.cc/6796-8ZKQ].

30 About, KARENGNONDI WATER AUTH., http://www.karegnondi.com/ [https://perma.cc/WXF3-K3QN] (last visited May 18, 2016).

31 Emergency Manager, Resolution Authorizing Approval to Enter into a Professional Engineering Serivces Contract for the Implementation of Placing the Flint Water Plant into Operation, (June, 26, 2013), http://mediad.publicbroadcasting.net/ [https://perma.cc/H96ZHWDN]; see also The Ctr. For Michigan, Michigan Truth Squad: Who Approved Awitch to Flint River? State’s Answers Draw Fouls, MLIVE (Jan. 21, 2016, 1:18 PM), http://www.mlive.com/ [https://perma.cc/JWY2-4TJV].

32 Adams, supra note 27.

${ }^{33}$ Sarah Schuch, Flint Residents Should be Drinking Flint River Water By Mid-April, Officials Say, MLIVE (Mar. 12, 2014, 6:10 PM), http://www.mlive.com/ [https://perma.cc/QUA4-44XN]. 
But, a significant number of the pipes that delivered water to those in Flint were lead pipes. ${ }^{34}$ Corrosion controls were not used upon the switch, which allowed lead to leach into the water supply. ${ }^{35}$ Shortly after the switch, Flint residents began to complain about the color and taste of the water. ${ }^{36}$ In October 2014, General Motors announced that it would cease to use water from the Flint River after discovering damage to its parts. ${ }^{37}$

Flint residents continued to express concerns about the water. In February 2015, the City of Flint tested the home of Flint resident LeeAnne Walters, and test results indicated a high level of lead. ${ }^{38}$ Subsequently, Walters contacted the Chicago office of the Environmental Protection Agency ("EPA"), where Miguel del Toral, Regulations Manager in the Regional Groundwater and Drinking Water Department, called the results "alarming." 39 In June 2015, del Toral, wrote an internal memo where he stated that the absence of corrosion controls in the water was a public health concern and gave recommendations for further EPA action. ${ }^{40}$

Walters had called Marc Edwards to get assistance with testing water in Flint. ${ }^{41}$ In September 2015, Marc Edwards, a professor of engineering and water resources at Virginia Tech University, determined that the corrosiveness of Flint water was causing lead to leach into Flint's water supply. ${ }^{42}$ Weeks later, doctors from Hurley Medical Center in Flint released a report indicating that, in communities affected by the switch to the Flint River, the proportion of infants and children with elevated levels of lead in their blood had nearly doubled since the switch. ${ }^{43}$

${ }^{34}$ Press Release, City of Flint, New UM-Flint Research Shows Location of Lead Pipes in Flint (Feb. 22, 2016) https://www.cityofflint.com/ [https://perma.cc/VNW6-HMPH].

${ }^{35}$ Nancy Kaffer, Why Didn't Flint Treat Its Water? An Answer, At Last, Detrolt FreE Press (Mar. 31, 2016, 5:01 PM), http://www.freep.com [https://perma.cc/B3J8-JZ9S].

${ }^{36}$ See, e.g., Ron Fonger, City Adding More Lime to Flint River Water as Resident Complaints Pour In, MLIVE (Jun. 12, 2014 2:30 PM, http://www.mlive.com/ [https://perma.cc/8TCZ-SFM8] (last updated Jan. 17, 2015, 10:10 AM); Mike Colias, How GM Saved Itselffrom Flint Water Crisis Rusting Engine Blocks Flagged Big Problem, Automotive NeWs (Jan. 31, 2016, 12:01 AM), http://www.autonews.com/ [https://perma.cc/C4M8-UHQR].

${ }^{37}$ Ron Fonger, General Motors Plant Won't Use Flint Water Until KWA Pipeline Complete, MLIVE (Oct. 12, 2015, 1:16 PM), http://www.mlive.com/ [https://perma.cc/J7MX-5S7U].

38 Jeremy C.F. Lin et al., Events That Led to Flint's Water Crisis, N.Y. TIMES, http://www.nytimes.com/interactive/2016/01/21/us/flint-lead-water-timeline.html?_r=0

[https://perma.cc/UJ48-2XFL] (last visited May 18, 2016).

${ }^{39}$ Memorandum from Miguel A. Del Toral, Regulations Manager, Ground Water and Drinking Water Branch, U.S. Env't Prot. Agency, to Thomas Poy, Chief, Ground Water and Drinkin Water Branch, U.S. Env't Prot. Agency 2-3 (June 24, 2015) http://flintwaterstudy.org [https://perma.cc/D78C-5UVP].

${ }^{40} \mathrm{Id}$. at $1-5$.

${ }^{41}$ John McQuaid, Without These Whistleblowers, We May Never Have Known the Full Extent of the Flint Water Crisis, SMITHSONIAN MAGAZINE (Dec. 2016), http://www.smithsonianmag.com/ [https://perma.cc/QZN9-VTKR].

${ }^{42}$ Kim Kozlowski, Virginia Tech Expert Helped Expose Flint's Water Crisis, Detroit News (Jan. 24, 2016, 6:34 PM), http://www.detroitnews.com/ [https://perma.cc/GX53-EAMG].

43 Pediatric Lead Exposure in Flint, MI: Concerns from the Medical Community, FLINTWATERSTUDY.ORG (2015), http://flintwaterstudy.org [https://perma.cc/5MFY-XAEU]. 
On October 1, 2015, the Genesee County Board of Commissioners declared a public health emergency and urged Flint residents to stop drinking the water unless it could be assured that it was lead-free. ${ }^{44}$ Amid the scrutiny, Flint reconnected to the Detroit River on October 16, 2015. ${ }^{45}$ Newly-elected Flint Mayor Karen Weaver declared a state of emergency on December 14, 2015, ${ }^{46}$ and the State of Michigan also declared a state of emergency on January 5, 2016. ${ }^{47}$

The Flint Water Crisis gained significant national media attention starting in January $2016 .{ }^{48}$ Since then, investigations have been launched to determine the cause(s) of the Crisis, several pieces of litigation are pending that seek to establish liability and damages, and community members and first responders are still trying to provide assistance to Flint residents.

Gina McCarthy, Administrator of the EPA, sent a letter to Michigan Governor Rick Snyder and Flint Mayor Karen Weaver in June 2016, identifying challenges that needed to be resolved, including the oversized water distribution system, staffing and operating problems at the water treatment plant, city administrative capacity, technical support, and a long-term decision for what will source Flint's water supply. ${ }^{49}$ She encouraged cooperation, stating that "the city and the state must work more closely together to resolve these long-term, systemic issues to ensure a safe and sustainable water supply for Flint residents." 50

As of July 2016, Flint residents are still waiting for permanent relief. A plan, to fix the city's pipes, has yet to be finalized, and residents are still relying on bottled water and water filters. ${ }^{51}$ Many residents remain skeptical that Flint water is safe to drink. ${ }^{52}$ Flint has identified a case of Legionnaire's disease in 2016, yet the extent and nature between the Flint Water Crisis and

${ }^{44}$ Genesee County Board of Commissioners, Public Health Emergency Declaration for People Using the Flint City Water Supply with the Flint Water as the Source (Oct. 1, 2015), http://www.gc4me.com [https://perma.cc/9VUY-2F4U].

45 Amanda Emery, Flint Reconnects to Detroit Water, May Take 3 weeks to Clear All Pipes, MLIVE (Oct. 17, 2015, 7:48 AM), http://www.mlive.com/ [https://perma.cc/3CSH-624T].

46 State of Emergency Declared in the City of Flint, CITY OF FLINT, https://www.cityofflint.com/state-of-emergency [https://perma.cc/46CP-B5V6] (last visited May 18, 2016).

${ }^{47}$ Governor Rick Snyder, Proclamation, Declaration of Emergency, MichigAN.Gov (Jan. 5, 2016), http://www.michigan.gov/ [https://perma.cc/E7QB-AZ79].

${ }^{48}$ Denise Robbins, Analysis: How Michigan and National reporters Covered The Flint Water Crisis, Media MATTERS FOR AMERICA (Feb. 2, 2016, 3:30 PM), https://mediamatters.org/ [https://perma.cc/L94V-T28V].

49 Letter from Gina McCarthy, Adm'r of the Environmental Protection Agency, to Mich. Governor Rick Snyder and Flint Mayor Karen Weaver 1, 2 (June 16, 2016) https://www.epa.gov/ [https://perma.cc/R95W-PGYD].

${ }^{50} \mathrm{Id}$. at 3.

51 See, e.g., Elisha Anderson, Flint's Broken Trust: 'I just can't continue living like this,' Detroit FreE PrESS (July 3, 2016, 12:47 PM), http://www.freep.com [https://perma.cc/9KQ9F9TA].

52 Jiquanda Johnson, Poll: Is Filtered Flint Water Safe to Drink?, MLIVE (July 1, 2016, 6:00 AM), http://www.mlive.com/ [https://perma.cc/84EV-SKD4]. 
Legionnaire's occurrence are still not fully known. ${ }^{53}$ It is unknown for just how long Flint residents will have to wait until long-term solutions are implemented.

As a result, many Flint residents are frustrated by the persisting need to rely on bottled water, and some have protested these conditions. ${ }^{54}$ Community groups, such as Flint Lives Matter, have struggled to secure resources in order to help fellow residents access water. ${ }^{55}$ Disaster response resources from both the state and federal governments have also started to taper off as the crisis has continued, and the federal state of emergency expired on August 14, 2016. ${ }^{56}$ Researchers released information in August 2016 stating that lead removal efforts had been making progress, though the water is not yet safe to drink. ${ }^{57}$

\section{The Potential of INTERPROFESSIONAL COLLABORATION IN THE FLINT WATER CRISIS}

The term interprofessional collaboration is often used in a clinical context to describe efforts to encourage different healthcare providers to work in integrated teams to provide patient care that is higher quality and has fewer errors. ${ }^{58}$ Interprofessional collaboration is also used as a framework to educate and encourage healthcare students to work in teams to communicate and coordinate in order to provide better patient care. ${ }^{59}$ Interprofessional collaboration is "based on the concept that when providers consider each other's perspective, including that of the patient, they can deliver better care." 60

${ }^{53}$ Gary Ridley, Flint-area's first Legionnaire's disease case confirmed for 2016, MLIVE (July 6, 2016, 2:38 PM), http://www.mlive.com [https://perma.cc/W5AK-CTCB].

${ }^{54}$ See, e.g., Rachel Woolf, Water Crisis Demonstration Uses 80 Cases of Bottled Water Fill Kiddie Pool, MLIVE (June 27, 2016, 10:45 PM), http:/www.mlive.com/ [https://perma.cc/T8X8YMLF].

${ }^{55}$ Michael Kransz, Flint Lives Matter Overcomes Funding Challenges to Give Out More Water, MLIVE (July 9, 2016, 8:30 PM), http://www.mlive.com/ [https://perma.cc/FNU2-JZRX].

${ }^{56}$ Merrit Kennedy, Federal State Of Emergency Over Lead-Laced Water Ends In Flint, Mich., NPR (Aug. 14, 2016, 11:28 AM), http://www.npr.org/sections/thetwoway/2016/08/14/489971417/federal-state-of-emergency-over-lead-laced-water-ends-in-flintmich [https://perma.cc/L7P9-4XM3].

${ }^{57}$ Nana Adwoa Antwi-Boasiako \& Gretchen Frazee, Lead Removal from Flint Water Making Progress, Researchers Find, PBS (Aug. 11, 2016, 1:51 PM), http://www.pbs.org [https://perma.cc/HRS9-94Q4]; see also Tonia Moxley, Virginia Tech Research Team Says Flint Water Improving, But Still Unsafe to Drink, The RoAnoke Times (Aug. 11, 2016, 9:30 PM), http://www.roanoke.com/ [https://perma.cc/F22M-C85Y].

${ }^{58}$ Robert Wood Johnson Foundation: Health Policy Snapshot, What can be done to encourage more interprofessional collaboration in health care?, (Sept. 2011), http://www.rwjf.org/ [https://perma.cc/PC9Z-CPK8].

${ }^{59}$ See Diane R. Bridges et al., Interprofessional Collaboration: Three Best Practice Models of Interprofessional Education, MED. EDUC. ONLINE, (Apr. 8, 2011), http://www.ncbi.nlm.nih.gov/pmc/articles/PMC3081249/ [https://perma.cc/7V42-DLWF].

${ }^{60}$ Charles P. Vega, M.D. \& Amy Bernard, M.S., BSN, RN-BC, Interprofessional Collaboration to Improve Health Care: An Introduction (Feb. 11, 2016) (source accessible via Medscape.com). 
Some in the public health community use interprofessional collaboration as a framework to help promote population health and improved public health outcomes. For example, the Association of Schools and Programs of Public Health released an updated Interprofessional Collaborative Practice Model framework in 2016. This framework lists core competencies, including assessing and addressing the "health care needs of patients and to promote and advance the health of populations." Another core competency is to "plan, deliver, and evaluate patient/population-centered care and population health programs and policies that are safe, timely, efficient, effective, and equitable." 61 As another example, interprofessional collaboration can serve as a foundation to help professionals in the public health community address socioeconomic barriers to health. ${ }^{62}$

The Flint Water Crisis has imposed, or has the potential to impose, several different harms to patient and population health, and there are several different categories of contributing factors. As a result, we believe that the Flint Water Crisis is a compelling example of the potential for interprofessional collaboration to help alleviate further harm in Flint. Just as important, we view the Flint Water Crisis as an important lesson in how interprofessional collaboration can prevent similar crises in other jurisdictions, in part because interprofessional collaboration may have prevented the Flint Water Crisis from happening.

We recognize that interprofessional collaboration is not a panacea for the harms imposed by the Flint Water Crisis. But for the following reasons, we contend that interprofessional collaboration is a necessary, though not sufficient, component of a long-term strategy to improve, and prevent further harm to, population health. In the following sections, we discuss how these principles have been and could have been applied to the Flint Water Crisis.

\section{A. How Can Interprofessional Collaboration Help Alleviate Further Harm in the Flint Water Crisis?}

There are several categories of activities that we consider as interprofessional collaborations that have started to address various problems that have developed since the Flint Water Crisis, especially after the Flint Water Crisis became more extensively publicized in the beginning of 2016. The following section contains examples of these interprofessional collaborations.

The first category pertains to providing assistance to help people affected by the Flint Water Crisis access several types of resources and services in the near-term. Flint residents have needed access to safe drinking water, either through bottled water or water filters. Some Flint residents have also needed access to health and nutritional services. ${ }^{63}$ Several philanthropic efforts have provided assistance to Flint residents, and there have been some nonprofit organizations that have used interprofessional collaboration to provide assistance. For example, Crossing Water, a nonprofit created in response to Flint Water Crisis, has assembled and deployed Rapid Response

61 Interprofessional Collaborative Practice Model, ASPPH, http://www.aspph.org/ [https://perma.cc/3SXP-TZCV] (last visited Oct. 31, 2016).

${ }^{62}$ See Allison A. Vanderbilt et al., Reducing Health Disparities in Underserved Communities via Interprofessional Collaboration Across Health Care Professions, 8 J. MulTIDISCIPLINARY HEALTHCARE, 205-208 (2015).

${ }^{63}$ Elisha Anderson, Flint's Growing Mental Health Crisis, Detroit FreE Press (Aug. 6, 2016, updated Aug. 7, 2016, 10:37 AM), http://www.freep.com/ [https://perma.cc/J64Q-BJKK]. 
Service Teams ("RRSTs"), which are interdisciplinary teams of social workers, nurses, emergency medical technicians, plumbers, and other technicians to provide resources and services to Flint residents in need. ${ }^{64}$ These teams also identify mental health, physical health, and material resource problems and coordinate assistance, and are working on long-term solutions for Flint residents. This effort is an example of interprofessional collaboration designed to address the health care needs of patients and help promote health at a population level that is a direct response to the effects of the Flint Water Crisis.

The second set of interprofessional collaborations focuses on responding to the potential health consequences of exposure to lead in both the short and long term, particularly among children under six years old when exposed to lead. For example, the newly-formed Pediatric Public Health Initiative, led by Dr. Mona Hanna-Attisha of Hurley Medical Center in Flint, plans to "bring together experts in pediatrics, child development, psychology, epidemiology, nutrition, toxicology, geography, education, and community workforce development" to address the "Flint community's population-wide lead exposure."65 The Pediatric Public Health Initiative's design is an example of interprofessional collaboration because professionals with different types of expertise are included in developing responses to the health consequences of the Flint Water Crisis. ${ }^{66}$

Also, some researchers have started working to better understand the causes of the Flint Water Crisis and develop ways to remediate its effects. For instance, some researchers are working to develop programming that would apply research findings in ways to assist Flint residents. Most importantly, several of these research projects include researchers from different professions, and are examples of interprofessional collaboration in the research context. For example, the University of Michigan School of Public Health has started efforts to "address the crisis through partnership-based interventions" $"$ with four primary goals in mind: 1) to focus on public health in the community, in a partnership context; 2) to advance and disseminate the science behind the issues; 3 ) to provide education and training; 4) to provide expertise and perspective. ${ }^{68}$ Wayne State University, based in Detroit, Michigan, has formed the Flint Area Community Health and Environment Partnership ("FACHEP"), to "evaluate the possible association between changes in Flint's water system and public health, specifically the recent Legionnaires' disease outbreak."69 These are two encouraging examples of interprofessional collaboration that are attempting to further understand the Flint Water Crisis through research and through creating programmatic solutions, though more interprofessional collaboration is required to fully understand the complexities and nuances of this problem.

${ }^{64}$ CROSSING WATER, http://crossingwater.org [https://perma.cc/7ZE4-4MJ9] (last visited Oct. 31, 2016).

${ }^{65}$ MSU-HURLEY Children's Hospital Pediatric Public Health Initiative, Mich. STATE UnIV., http://humanmedicine.msu.edu/pphi/About.htm [https://perma.cc/78HC-GGDP] (last visited Oct. 31, 2016).

${ }^{66} \mathrm{Id}$.

67 Addressing the Public Health Crisis in Flint, Univ. OF Mich. Sch. OF Pub. HeAlth, https://sph.umich.edu/flint-crisis/ [https://perma.cc/W9LW-R7UL] (last visited Oct. 31, 2016).

${ }^{68} \mathrm{Id}$.

${ }^{69}$ Mike Brinich, Wayne State research team to evaluate possible link between Flint water system and health problems, WAYNE STATE UNIV. (Mar. 1, 2016), http://wayne.edu/ [http://perma.cc/3QC6-TUC6]. 
While interprofessional collaboration has started to respond to some of the effects of the Flint Water Crisis, more interprofessional collaboration is still required to help Flint recover from the Flint Water Crisis. Additional interprofessional collaboration that can help preserve or improve population health outcomes. For example, continued and additional interprofessional collaboration can further help to address the funding and infrastructure issues associated with fixing the city's pipes and water supply in the long-term, ensuring that Flint residents have access to safe water in the future. Interprofessional collaboration can also help address the challenges in both poverty and economic development that the Flint Water Crisis has exacerbated.

\section{B. Could Interprofessional Collaboration Have Prevented the Flint Water Crisis?}

Some have asserted that the Flint Water Crisis was preventable. For example, in June 2016, the Centers for Disease Control and Prevention ("CDC") examined data on lead levels in children younger than six before, during, and after Flint's switch to the Flint River. ${ }^{70}$ In a press release accompanying the results of the analysis, Patrick Breysse, P.h.D., director of the CDC's National Center for Environmental Health, stated "This crisis was entirely preventable, and a startling reminder of the critical need to eliminate all sources of lead from our children's environment."71 Virginia Tech civil engineering professor Marc Edwards, whose testing helped identify the elevated lead levels in Flint's water" agreed, stating "What's happened is an entirely preventable man-made disaster that started out by not allowing federal law that requires the addition of a corrosion control chemical to the water supply to protect the iron and lead pipes from corrosion."73

In addition to arguments that the Flint Water Crisis was preventable, others have discussed potential ways to prevent similar situations from developing in the future. For instance, the Michigan Legislature established the Joint Select Committee on the Flint Water Public Health Emergency, and the committee released a report that contained "policy improvements to address the Flint water emergency and prevent similar emergencies throughout the state of Michigan."74 Likewise, articles have discussed the possibility of preventing events similar to the Flint Water Crisis in other places. ${ }^{75}$

${ }^{70}$ CDC Investigation: Blood lead levels higher after switch to Flint River Water, CTR. FOR Disease CONTROL AND PREVENTION (June 24, 2016, 11:00 AM), http://www.cdc.gov/ [https://perma.cc/6PW5-JQ8Z].

${ }^{71}$ Id.

72 See Colby Itkowitz, The Heroic Professor Who Helped Uncover the Flint Lead Water Crisis, ThE WASHINGTON POST (Jan. 27, 2016), https://www.washingtonpost.com/ [https://perma.cc/CP45-WA3H]; Kim Kozlowski, Virginia Tech Expert Exposed Flint Water Crisis, The Detroit News (Jan. 23, 2016, 10:24 PM, updated Jan. 24, 2016, 6:34 PM), http://www.detroitnews.com/ [https://perma.cc/R5VX-YJB3].

73 Adam Wernick, The water crisis in Flint is 'an entirely preventable man-made disaster', PUB. RADIO INT'L (Feb. 6, 2016, 9:00 AM), http://www.pri.org/ [http://perma.cc/V953-CKT8].

74 The JoInt COMm. ON THE Flint WATER Pub. HeAlth EMERGENCY, Flint WATER CRisis, 2 2016.

75 See, e.g., Ron Fournier, How to Prevent the Next Flint, ThE ATLANTIC (Feb. 18, 2016), http://www.theatlantic.com/ [https://perma.cc/K7ZJ-ABVH]; Randy Lee Loftis, Could what Happened in Flint Happen Anywhere?, NATIONAL GeOGRAPHIC (Jan. 26, 2016), http://news.nationalgeographic.com/ [https://perma.cc/M3HQ-7EYX]. 
While it is impossible to know for certain if interprofessional collaboration would have prevented the Flint Water Crisis, if the Flint Water Crisis was at least potentially preventable, an important question to consider is whether interprofessional collaboration could have at least helped prevent it. We recognize that some relevant interprofessional collaboration may have occurred before Flint's water supply switched from the Flint to the Detroit River as organizations and universities have been collaborating on related issues in the Flint area. But at the time, lead poisoning from the water supply was not an issue in focus because the Crisis had not yet occurred.

We assert that interprofessional collaboration could have prevented the decision makers from either switching to the Flint River, or at least more proactively consider corrosion controls or other mechanisms to ensure water safety. First, interprofessional collaboration could have created or added to independent research, analysis, and projections for the potential economic, environmental, and health consequences of switching to the Flint River. As discussed above, the evidence available shows that significant amount of focus in this decision-making process focused on financial and economic incentives and consequences. Some in the City of Flint and emergency management were looking for a less costly way to procure water. We assert that more interprofessional collaboration could have helped analyze the risks of lead exposure and the costs from both public health and economic perspectives, and it could have helped engender more discussions about the infrastructure costs of each option.

Perhaps such exploration may have been facilitated if Flint had professionals engaging in interprofessional collaboration and policy makers following a Health in All Policies Framework ("HiAP") operating at the time this decision was made. HiAP is a "collaborative approach to improving the health of all people by incorporating health considerations into decision-making across sectors and policy areas." ${ }^{76} \mathrm{HiAP}$ is a framework developed with a broader focus on social determinants of health. HiAP calls for "promoting health and equity, supporting intersectoral collaboration, creating co-benefits for multiple partners, engaging stakeholders, and creating structural or process change." 77 The use of the HiAP framework may have prompted a discussion about potential negative effects of switching the water supply to the population's health. Perhaps if policymakers could have considered all of these factors at the same time, there could have been, at a very minimum, more exploration of alternative options.

\section{STRENGTHENING INTERPROFESSIONAL COLLABORATION BEYOND THE FLINT WATER CRISIS}

The Flint Water Crisis is not resolved, especially as many Flint residents cannot access safe drinking water from their taps, and we assert that interprofessional collaboration must continue and increase in order to help bring it to some kind of resolution. The Flint Water Crisis provides different types of professionals within the public health community an opportunity to reflect upon and strategize on how to mitigate other current water crises and prevent similar types of crises in the future. The need for a strategy is urgent-Flint, Michigan is not alone. There are many cities that are also struggling financially and have lead pipes that could contaminate water supplies. There are most likely similar water crises either occurring or developing that have not yet

${ }^{76}$ Linda Rudolph et. al., Health in All Policies: A Guide for State and Local Governments AM.

Pub. Health Ass'N AND Pub. Health Inst. 5 (2013), http://www.phi.org/ [http://perma.cc/2SEA-PJND].

${ }^{77}$ Id. 
generated much news attention. An example is the situation in St. Joseph, Louisiana, which came to national attention in February 2016. Like Flint, water in St. Joseph was frequently discolored, and it had been a recurring problem for several years. ${ }^{78}$ The cause of the discoloration was likely a broken pipe. ${ }^{79}$

In the United States, there are approximately six million lead lines, about seven percent of homes that are connected to community water systems have a lead service line, and up to twentytwo million Americans are served by lead lines. ${ }^{80}$ A 2013 Government Accountability Office ("GAO") report also illustrated many cities' need for water infrastructure assistance from the federal government. ${ }^{81}$

To address the threat of potential new water crises in a time when the United States has many vulnerable communities and many pieces of aging infrastructure, interprofessional collaborations that can help prevent and respond to these crises need to be sustained and supported. This kind of crisis can impose a profound economic burden on governments and several types of burdens on affected communities, including large engineering and construction challenges, acute and chronic physical and mental health problems, and impediments to economic development.

Interprofessional collaboration is necessary to prevent and respond to future water crises like that in Flint, and interprofessional collaboration must not be considered merely helpful or an opportunity. Instead, along with the HiAP framework, interprofessional collaboration should be treated as a policy and practical imperative. The consequences of these crises are complex and interwoven, and interprofessional collaboration is necessary to understand how those consequences manifest in a particular situation. Interprofessional collaboration is also required to assist, or sometimes be the only, form of direct assistance to communities affected by these crises. And, when there is inaction or delay in a broader response to such a crisis, like what occurred in Flint, interprofessional collaboration can help spur action.

Sometimes, interprofessional collaboration can and should occur on an ad hoc basis when a specific, new problem arises, which is what happened in large part in the Flint Water Crisis. But an infrastructure that enables regular, consistent interprofessional collaboration can help identify potential crises, prevent those crises from happening in the first place, or efficiently mitigate those crises.

One potential mechanism that might support sustained efforts of interprofessional collaboration is Public Health 3.0, a relatively new initiative led by the U.S. Department of Health and Human Services, Office of the Assistant Secretary for Health that continues the work of the

${ }^{78}$ Beyond Flint: In The South, Another Water Crisis Has Been Unfolding For Years, NPR (Feb. 6, 2016, 6:20 AM), http://www.npr.org/ [https://perma.cc/WS5K-ZXR8].

${ }^{79}$ Id.

${ }^{80}$ Henry Cisneros, A National Water Crisis: Fixing the water infrastructure is one of the greatest challenges of our time., U.S. NEws (June 29, 2016, 6:00 AM), http://www.usnews.com/ [https://perma.cc/TA2G-LJZJ].

81 U.S. GOV'T ACCOUNTABILITY OFF., GAO-13-451T, WATER INFrASTRUCTURE: APPROACHES AND ISSUES FOR FINANCING DRINKING WATER AND WASTEWATER INFRASTRUCTURE (2013), http://www.gao.gov/assets/660/652976.pdf [https://perma.cc/Q3G3ZPKF]. 
Healthy People 2020 initiative ${ }^{82}$ It is a "modern version that emphasizes cross-sector collaboration and environmental, policy, and systems-level actions that directly affect the social determinants of health." ${ }^{83}$ And "it represents a challenge to business leaders, community leaders, state lawmakers, and Federal policymakers to incorporate health into all areas of governance." ${ }^{84}$ The framework currently focuses on the following elements: enhanced leadership and workforce, new partners; technology, tools, and data that matter, new metrics of success, and funding. ${ }^{85}$ Public Health 3.0 is an opportunity to continue to build a platform for interprofessional communication and collaboration across the country around many public health topics, including these kinds of potential crises.

This convening effort can also help to address other crises like the Flint Water Crisis by explicitly naming crisis prevention as a priority, which would also support efforts to promote health equity and better social determinants outcomes. This convening effort needs to also encourage and engender participation from professionals who would otherwise not think to or be inclined to participate in efforts that have a public health focus. Progress has been made in this area in efforts to generally address social determinants of health. Nonetheless, further efforts are needed to engage engineers to think about how to make infrastructure repairs and people with economic development expertise to think about how to create economic opportunities and control overall costs. This project also provides an opportunity for lawyers to engage by advising on the legal ramifications of different decisions.

The incorporation of social determinants of health in these discussions provides a pathway for professionals who are customarily less engaged in public health to focus on public health outcomes, and it allows for those who focus on public health to gain more exposure to implications and consequences of decisions in other settings. This suggests further that other states and localities facing similar situations with municipalities in fiscal distress should consider a HiAP strategy as one criterion for responding to fiscal distress.

More interprofessional collaborations are necessary in order to address this large, nationwide problem that may manifest itself differently by state or by community. The various types of interprofessional collaborations started as a response to the Flint Water Crisis, as well as the frameworks discussed in this essay, provide a foundation for other interprofessional collaborations.

\section{CONCLUSION}

Right now, it is impossible to know how long it will take for the Flint Water Crisis to reach a final resolution, and it will certainly take years to understand the long-term impacts of the elevated

82 Public Health 3.0, HealthyPeople.gov, https://www.healthypeople.gov/2020/toolsresources/public-health-3 [https://perma.cc/WQM2-D2GY] (last visited May 18, 2016).

${ }^{83}$ Karen B. DeSalvo et al., Public Health 3.0: Time for an Upgrade, 106 Am. Pub. Health Ass'N 621, 622 (2016), https://healthycommunities.files.wordpress.com_[https://perma.cc/ACU5Q7MZ].

84 Public Health 3.0, HealthyPeOPle.GOV, https://www.healthypeople.gov/2020/toolsresources/public-health-3 [https://perma.cc/WQM2-D2GY] (last visited May 18, 2016).

${ }^{85}$ See Karen B. DeSalvo et al., Public Health 3.0: Time for an Upgrade, 106 Am. PuB. Health Ass'N 621, 622 (2016), https://healthycommunities.files.wordpress.com/ [https://perma.cc/ACU5-Q7MZ]. 
lead exposure on those affected by the crisis. We believe that continued interprofessional collaboration is required to further understand and mitigate the harms imposed by the Flint Water Crisis.

It is also vitally important to remember that Flint is not the only community in the country with an infrastructure susceptible to similar problems, and that Flint is not the only community facing problems, or potential problems, with lead in its water supply. ${ }^{86}$ Also, water is not the only resource that can be contaminated through policy decisions. As economic recovery and development continue to be uneven throughout the nation, and infrastructure investments are lacking, it is reasonably likely that other cities and states are likely to see more crises similar to the Flint Water Crisis. These crises compromise public health. The public health community has an opportunity to build interprofessional collaborations at a local, state, and national level not only to strive to maintain and improve population health, but also to prevent population health outcomes from getting worse.

${ }^{86}$ See, e.g., Mark Pattison, Lead in the water: The crisis is not solely Flint's (Jul. 9, 2016), https://www.ncronline.org/ [http://perma.cc/KK7S-CYH6]; see also Alex Zielinski, an Indiana city is poised to become the next Flint, https://thinkprogress.org/ [http://perma.cc/M56X-Q8VY] (last visited Oct. 31, 2016) (concerning toxic soil, but a similar problem). 